Visit us - www.researchjournal.co.in — DOI : 10.15740/HAS/IRJAES/7.2/248-250

\title{
Research Paper Farmers perception towards crop insurance scheme
}

\section{PALLAVI D. KANGALE, A. N. DESHMUKH AND SONALI A. DESHMUKH}

See end of the paper for authors' affiliations

Correspondence to :

\section{A.N. DESHMUKH}

Department of Extension Education, Shri Shivaji Agriculture College, AMRAVATI (M.S.) INDIA

\section{Paper History :}

Received : 22.06.2016;

Revised : 12.08.2016;

Accepted : 29.08.2016
Abstract : The present study on farmers perception towards crop insurance scheme was conducted in the year 2015-16 in Amravati district. For this study 100 respondents were purposively selected from two tahsils of district with the help of random sampling method. Frequencies, mean, standard deviation, correlation of co-efficient analysis were employed for interpreting the results. Findings of relational analysis revealed that education, subsidiary occupation, extension contacts, social participation, benefits availed, crops covered in crop insurance were positively and significantly correlated with perception and age, annual income, farming experience, source of information were negatively but significantly correlated with perception except land holding and loan availed from bank which were non-significantly related with perception. Crop diversification, forward marketing, adjustment of investment, timeliness of the field operations were the important risk management strategies adopted by the farmers in view of loss occurred to crop failure.

KEY Words : Perception, Crop insurance, Risk management strategies

How To Cite This PAper : Kangale, Pallavi D., Deshmukh, A.N. and Deshmukh, Sonali A. (2016). Farmers perception towards crop insurance scheme. Internat. Res. J. Agric. Eco. \& Stat., 7 (2) : 248-250, DOI : 10.15740/ HAS/IRJAES/7.2/248-250. 